\title{
English Writing Performance Using Blended Learning in TVET Education
}

\author{
Ayuni Madarina Abdul Rahman \\ Faculty of Language and Communication \\ Universiti Sultan Zainal Abidin, 21030 Kuala Nerus, \\ Terengganu, Malaysia \\ Email: ayunie858@gmail.com
}

\begin{abstract}
This study focuses on Technical and Vocational Education and Training (TVET) covering formal, non-formal and informal learning preparing young people with the knowledge and skills required in the world of work. English has become an important language in Malaysian higher learning institutions used as a medium of interaction and for other educational purposes. For this study, the researcher would like to highlight the impacts of blended learning on students' writing performance. This is due to the concerns regarding students' difficulty in English writing. The study used experimental research design to conduct the study that involved 60 students from semester 1 who took Communicative English 1. The study has been conducted on two groups, which were experimental and control group. The students had to answer the questionnaire regarding teacher centred approach (control group) and blended learning approach (experimental group). Students also do writing test to be correlated with the result from questionnaire of SPSS version 23 using Kendall's correlation as a tool to analyse the result. The result shows that blended learning has a positive effect to most of students in experimental group.
\end{abstract}

Keywords: blended learning, teacher centred approach, writing skill, students' perception

\section{Introduction}

Teaching and learning English as a second language has become an influential area in Malaysian educational field. There are beneficial studies pertaining to the teaching and learning of the four language skills which are listening, speaking, reading and writing 
(Banditvilai, 2011; Permana, \& Gede, Y., 2017). In addition, the advancement of technology in education has widespread implication on English language classroom.

English has become an important language in Malaysian higher learning institutions that is used as a medium of interaction and for other educational purposes (Darmi \& Albion, 2013). Thus, Malaysian students are required to master the English language and measures are taken to achieve it (Thirusanku \& Yunus, 2014). Highlighting its importance for education, career as well as networking purposes, students are required to be able to comprehend English and able to communicate this language well (Kadir \& Noor, 2015). However, the quality of English proficiency among Malaysian students is reported declined as cited in Malaysia Education Blueprint (2013).

Students coming to class have a wide assortment of requirements, interests, previous information, and support making this a challenge for instructors to separate to these requirements while expanding all students' level of comprehension. School is moving far from the one size-fits-all lesson design and educators' lesson plan must be advanced out of their usual range of comfort zone and push new ideas keeping in mind the end goal to promote the learning of every last one of their students.

For this study, the researcher would like to highlight the impacts of blended learning on students' writing performance. This is due to the concerns regarding students' difficulty in English writing. Darus and Kaladevi (2009) analysed 72 written essays and the findings of the study indicated that students generally have problems in applying correct grammatical rules in their writings.

\section{Literature Review}

\subsection{Students' Perception towards Blended Learning}

Hall, S., \& Villareal, D. (2015) conducted a study entitled The hybrid advantage: Graduate student perspectives of hybrid education courses. The students were involved in online learning activities for instance course content provided by the educators was presented in online medium using Microsoft Power Point and Prezi Presentations. The result of this study has shown that students were able to develop their learning understanding and heighten their motivation level. Nevertheless, the strengths of the online learning can be well equipped with the support from educators, varied learning content, and ability to provide materials according to students learning preferences and this will be able to vary students' learning outcomes. Wichadee (2017) concluded that students in experimental group who used EDMODO as one of the tools indicated for having better learning achievement, will have higher motivation and more positive attitude than traditional group. 


\subsection{Teaching Writing Online}

Composing adequately is a fundamental skill that all students should ace (Purnawarman, et. al., 2016). Permanda and Gede (2017) investigated the effect of using blended learning strategies towards students' writing competency. The research design used is experimental design called Post-test Only Control Group Design involving an experimental group and a control group which were formed by cluster random sampling comprising 28 students for each group. The teacher used blended learning for experiment group and meanwhile using traditional method to teach control group. The data were analyzed by using t-test and descriptive analysis. The students took the writing test after the implementation of the treatment. From the results obtained, students in experimental group shows a significant effect on their writing competency. Descriptively, experimental group scored $84.75 \%$ while control group scored lower, $76.75 \%$ of the writing test. This illustrates that teaching writing using blended learning has enabled students to have better performance as compared to students who learned through conventional approach. In coherent, Akkonyunlu and Soylu (2015), stated in their study, that students were motivated and becoming more engaged when provided with blended learning classroom.

McCall (2017) explored the usage of microblogs on Facebook to develop students' academic reading and writing skills. The researcher applied an action research using quantitative and qualitative data collection involving classroom observation, survey and interview. The teacher set up a Facebook microblog to have an online class session with the students. The teacher will post a picture or articles for students to read, report, and comment. Based on the discussion of the study, students positively responded to the use of Facebook application as to perform reading and writing tasks. They viewed blended learning approach as an interactive and creative ways of learning. Thus, integrating social media platform in teaching and learning specifically for English course will be beneficial for both students and teachers.

\subsection{Teacher Centred Approach}

Teacher-centred learning has its aims, methods of instruction, and discipline on things handed down from the past and transmitted in a static way to the pupils directly as an end product with no active participation of them (Eldeeb, 2013). Vocabulary ramification vs traditional learning instruction in an inclusive high school classroom is the title for study conducted by Nahmod (2017) where she used different learning approaches in teaching vocabularies to students. One of the approaches is teacher centred approach. Students were divided into two groups. Students in teacher centred approach were provided with vocabulary worksheet at the beginning of each week where the teacher taught to pronounce words and followed by the students. These activities implied in the classroom showed how teacher centred approach was used in this language classroom. Students will follow teacher's instruction without any 
enquiries in order to complete their task. Students were not give autonomous roles towards their own learning. Johnson, L. \& Micheal, W.V. (2016) described teacher centred approach is a centre of attraction in the class, playing vital authority role, and planning the lessons to students.

\section{Research Method}

\subsection{Experimental Research Design}

Quantitative research design is used in this study to collect the data from students' writing tests. Harwell (2011) mentions that key features of quantitative study are the use of instruments such as tests or surveys to collect data, and reliance on probability theory to test statistical hypotheses that correspond to research questions of interest.

Quasi-experimental is the manipulation of independent variable and the absence of randomization selection. Jaikumar (2014) mentions that non-randomized control group (NRCG) is familiar with pre-test and post-test design except there is a randomization limitation of the participants in control and treatment group. In NRCG, dependent variables are observed in treatment as well as control group in pre-test. Later, the post-test observation of dependent variables is to be carried out to examine the impacts of the intervention.

For this study, the researcher used quasi-experimental and focused on NRCG to collect data from dependent variables of this study which is the result for writing performance after blended learning intervention. Therefore, it is very crucial to use this approach in order to examine the outcomes after blended learning is used in teaching writing.

\section{Discussion}

Results and Data Analysis for Control and Experimental Groups

Respondent's Demographic Data Group A (Control Group) Descriptive Statistics

\begin{tabular}{llcl}
\hline D1: Gender & Male & Frequency & Percent \\
& Female & 5 & 16.7 \\
& Total & 25 & 83.3 \\
& 18-19 years & 30 & 100.0 \\
D2: Age & Malay & 30 & 100.0 \\
D3: Race & & 30 & 100.0 \\
$\begin{array}{l}\text { D4: Period of } \\
\text { Learning English }\end{array}$ & 7 years and above & 30 & 100.0 \\
& & & \\
\end{tabular}


D5: English SPM Result

$\begin{array}{lll}\text { B } & 5 & 16.7 \\ \text { C } & 11 & 36.7 \\ \text { D } & 14 & 46.7 \\ \text { Total } & 30 & 100.0\end{array}$

The total sample of 30 obtained from respective Polytechnic had a gender breakdown of $83.3 \%$ female and $16.7 \%$ male for Group A. $100 \%$ was aged from $18-19$ years and Malay. $100 \%$ of respondents were learning English more than 7 years and their English SPM results were varied. The lowest is $16.7 \%$ who reported scored B grade, $36.7 \%$ scored $C$ grade and the highest percentage was $46.7 \%$ scored $D$ for the subject.

Respondent's Demographic Data Group B (Experimental Group)

\begin{tabular}{llll}
\hline & & Frequency & Percent \\
D1: Gender & Male & 6 & 20.0 \\
& Female & 24 & 80.0 \\
& Total & 30 & 100.0 \\
D2: Age & 18-19 years & 30 & 100.0 \\
D3: Race & & & \\
D4: Period of Learning & & 30 & 100.0 \\
English & & & \\
& 7 years and & 30 & 100.0 \\
D5: English SPM Result & above & & \\
& B & & 20 \\
& C & 6 & 30 \\
& D & 13 & 43.3 \\
& E & 2 & 6.7 \\
& Total & 30 & 100.0 \\
\hline
\end{tabular}

Similarly, the total sample of 30 obtained from respective Polytechnic where $80 \%$ were female and $20 \%$ male for Group B. $100 \%$ was aged from $18-19$ years and Malay. $100 \%$ of respondents were learning English for more than 7 years nevertheless their English SPM results were varied. The lowest is $6.7 \%$ who reported scored $E$ grade, $20 \%$ scored $B$ grade and the highest percentage was $43.3 \%$ scored $D$ for the subject. 


\section{Kendall's Correlation Coefficient Analysis between Students' Perceptions and Students' Writing Performance}

(Group A)

Correlations

\begin{tabular}{lllcl}
\hline & & & $\begin{array}{c}\text { Students' } \\
\text { Perceptions }\end{array}$ & $\begin{array}{c}\text { Students' Writing } \\
\text { Performance }\end{array}$ \\
\hline Kendall's tau_b & $\begin{array}{l}\text { Students' } \\
\text { Perceptions }\end{array}$ & $\begin{array}{l}\text { Correlation } \\
\text { Coefficient }\end{array}$ & 1.000 & .048 \\
& & Sig. (2-tailed) &. & .742 \\
& S & Correlation & .048 & 30 \\
& Writing & Coefficient & 1.000 \\
& Performance & Sig. (2-tailed) & .742 &. \\
& $\mathrm{~N}$ & 30 & 30 \\
\hline
\end{tabular}

(Group B)

Correlations

\begin{tabular}{lllll}
\hline & & $\begin{array}{c}\text { Students' } \\
\text { Perceptions }\end{array}$ & $\begin{array}{c}\text { Students' Writing } \\
\text { Performance }\end{array}$ \\
\hline Kendall's tau_b & Students' & Correlation & 1.000 & .097 \\
& Perceptions & $\begin{array}{l}\text { Coefficient } \\
\text { Sig. (2-tailed) }\end{array}$ &. & .517 \\
& & N & 30 & 30 \\
& Students' & Correlation & .097 & 1.000 \\
& Writing & Coefficient & .517 &. \\
& Performance & Sig. (2-tailed) & .50 & 30 \\
& & N & 30 & \\
\hline
\end{tabular}

A statistical package known as IBM SPSS version 23 was used to conduct Kendall's tau b correlation analysis between Students' Perceptions and Students' Writing Performance. The strength of the relationships was used to evaluate the correlations where coefficients between .10 to .29 represent a weak association, coefficients between .30 to .49 represent a medium association and coefficients above .50 considered strong associations as cited in Cohen (1988).

From the table above, there was a weak correlation between Students' Perceptions and Students' Writing Performance $(r=0.048)$ for Group A. Similarly, Group B also presents a weak correlation between Students' Perceptions and Students' Writing Performance $(r=0.97)$. However, students who learned using blended learning approach scored higher than those in teacher centred approach. As discussed in earlier section, students' perception towards both approaches indicating positive direction that can be associated with their writing performance. 
This results show that, students' perceptions were basically based on their personal learning experience in Communicative English 1 course, in which, students in Control Group learned through face-to-face interaction with the teacher, listened to lecturers, read lecture notes and did exercises given by tutors in the classroom.

Additionally, students who learned in teacher centred approach has not received varied learning activities that might motivate them to perform in the class. Students in control group did not show reciprocal interaction from students to students and students to teachers. This is coherent to teacher centred approach that has been discussed previously where teacher-centred learning has its aims, methods of instruction, and discipline on things handed down from the past and transmitted in a static way to the pupils directly as an end product with no active participation of them (Eldeeb, 2013).

Meanwhile, students in blended learning used computers, internet, social media and peer feedback as part of their learning and some of the works can be done outside of the classroom. Akkonyulu and Soylu (2015) highlighted that students' active engagement can be seen when using blended learning approach as seen in their active engagement in online learning platform to perform their weekly tasks. This makes them able to learn in flexible mode at their own speed.

From this study, though the relationship is weak, it can be seen that, blended learning activities that have been used by the lecturer in the class promote improvement for students' writing as cited in Wichadee (2017). Activities used such as following diamond design templates, sharing writing task, giving feedback, having group discussion, utilizing reciprocal interaction between classmates and lecturer have contributed to students' writing enhancement. These learning activities have shown that students were able to construct their own learning that have been mixed with previous knowledge. Thus, the impacts of different learning strategies and activities can be seen in students' performance.

Therefore, students who learned through the implementation of blended learning approach have obtained better results in their writing concordance to their perception. Thus, educators might consider to mix traditional approach with technological advances and online activities that can accelerate students' English learning specifically in writing skills. Nonetheless, the adopters of blended learning approach must consider the challenges and barriers that might be encountered to avoid any unnecessary incidents during the implementation.

Looking at students' writing performance, it can be concluded that student in experimental group outperformed students in control group. As discussed earlier, the benefits of blended learning approach when it is appropriately utilized will able to result in students learning improvement. The result of this study has shown that students were able to develop their learning understanding and heighten their 
motivation level as cited in Hall \& Villareal (2015). Aligned with this, from the study conducted, the researcher found that $88 \%$ of students were able to perform basic computer skills by themselves and $76 \%$ of them could utilize internet skills. Students were involved in online activities such as participating in e-forums, emails, and websites among their colleagues.

\section{Conclusion}

The study shows that blended learning has a positive effect on most students experimental group and the researcher would continue to incorporate this learning tool in more of the writing lessons. Amid this investigation the researcher proposed to examine which group, teacher centered or blended learning approach will create a superior learning result on students writing performance. The reason for both instructional approaches was for students to have varied capabilities to learn appropriate sentence structure, writing techniques and apply it to their written work. Composing adequately is a fundamental skill that all students should ace (Purnawarman, et. al., 2016). The study research question was about which learning group was more successful with the intention of both groups gaining some success. While both groups did gain success, the blended learning group showed more improvement in the writing task given throughout the study.

\section{References}

Akkoyunlu., B., \&Soylu., M.Y. (2015). A study of student's perceptions in a blended learning environment based on different learning styles. International Journal of Education and Development using Information and Communication Technology(IJEDICT), 11, 80-100.

Banditvilai, C. (2011). Enhancing Students' Language Skills Through Blended Learning. The Electronic Journal of e-Learning, 14 (3), 220-229. Retrieved from www.ejel.org/issue/download.html?idArticle $=508$

Darmi, R., \& Albion, P. (2013). English language in the Malaysian education system: its existence and implications. 3rd Malaysian Postgraduate Conference (MPC2013), 175-183. Retrieved from http://eprints.usq.edu.au/id/eprint/24021

Darus, S., \&Subramaniam, K. (2009). Error Analysis of the Written English Essays of Secondary School Students in Malaysia: A Case Study.European Journal of Social Sciences, 8 (3), 483-495.

Eldeeb, R. (2013). Review and Critique of the Book "Education And Experience" by John Dewey. IOSR Journal of Research \& Method in Education, 1(2), 44-47. Retrieved from www.iosrjournals.org/iosr-jrme/papers/Vol1\%20lssue2/I0124447.pdf?id=1665

Hall, S., \& Villareal, D. (2015). The Hybrid Advantage: Graduate Student Perspectives of Hybrid Education Courses. International Journal of Teaching and Learning in Higher Education, 27(1), 69-80. 
Harwell, R. (2011). The SAGE Handbook for Research in Education: Pursuing Ideas as the Keystone of Exemplary Inquiry. USA: SAGE Publications.

Johnson, L. \& Micheal, W.V. (2016). Approaches to teaching EMS: The teacher-centred approaches. 103-120.

Jaikumar, J. (2014). Research Approach and Design. Retrieved from www.slideshare.net/maheswarijaikumar/approach-design.

Kadir, K.A., Noor, W.S.W.M. (2015). Students' Awareness of the importance of English Language Proficiency with Regard to Future Employment. World Review of Business Research, 5(3),259 - 272. Retrieved from http://www.wrbrpapers.com/static/documents/September/2015/18.\%20Kad zrina.pdf

McCall, H. (2017). Using microblogs on Facebook to develop students' academic reading and writing skills. Retrieved from faculty.edfac.usyd.edu.au/projects/usp_in_tesol/pdf/volume12/Article05.pdf

Nahmod, D. (2017). Vocabulary gamification vs traditional learning instruction in an inclusive high school classroom. Retrieved from http://rdw.rowan.edu/etd/2467

Purnawarman, Susilawati, and Sundayana, (2016). The use of Edmodo in teaching writing in a blended learning setting. Indonesian Journal of Applied Linguistics, 5(2), 242-252. Retrieved from ejournal.upi.edu > Home > Vol 5, No 2 (2016)

Permana, \& Gede, Y., (2017). The Effect of Using Blended Learning Strategy toward the 8 Grade Students' Writing Competency. Journal of Psychology and Instruction Retrieved from http://ejournal.undiksha.ac.id/index.php/JoPal/

Wichadee, S. (2017). A Development of the Blended Learning Model Using Edmodo for Maximizing Students' Oral Proficiency and Motivation. International Journal of Emerging Technologies in Learning, 12(2), 137-154. http://doi.org/org/10.3991/ijet.v12i02.6324

Thirusanku, J. \& Yunus. M.M. (2014). Status of English in Malaysia. Canadian Center of Science and Education, 10 (14), 254-260. Retrieved from http://www.ccsenet.org/journal/index.php/ass/article/viewFile/37998/21197 